\title{
George Comstock: um grande epidemiologista, uma figura humana ímpar
}

\section{George Comstock: a great epidemiologist, an unique human being}

Rio de Janeiro, 5 de setembro de 2007.

Senhores Editores,

A Epidemiologia mundial sofreu grande perda em julho passado, com o falecimento de George Comstock, aos 92 anos de idade.

Até as vésperas de sua morte, Comstock estava ativo em sala de aula na Universidade Johns Hopkins, onde lecionou por mais de 50 anos. Editor-chefe do American Journal of Epidemiology durante uma década e pesquisador louvado por seu pioneirismo na epidemiologia da tuberculose, suas contribuições originais envolveram muitos outros temas e estão registradas em mais de três centenas de artigos científicos. Algumas contribuições metodológicas desse cientista foram pioneiras, como o uso inovador de tabelas de vida, a avaliação da efetividade de vacinas, os estudos sorológicos de precursores de neoplasias e, em especial, a utilização do desenho de estudo caso-coorte. ${ }^{1}$

George Comstock foi comprometido com as aplicações do conhecimento epidemiológico na saúde pública, e conhecido por seu amor ao ensino e por suas relações afetuosas com alunos e discípulos. Dedicava-se à

\section{REFERÊNCIAS}

1. Szklo M. Population-based cohort studies. Epidemiol Rev. 1998;20:81-90.

2. Comstock GW. A conversation with George W. Comstock by Dale P. Sandler. Epidemiology. 2003;14:623-7. musica e a causas comunitárias, e se preocupava com a influência crescente do poder econômico sobre a pesquisa científica. ${ }^{2}$ Outros aspectos de sua vida pessoal e profissional estão relatados em obituário publicado pelo American Journal of Epidemiology. ${ }^{3}$

Tive a enorme sorte de conhecê-lo logo no início de meu doutoramento na Johns Hopkins (onde já me considerava suficientemente sortudo por ter Moyses Szklo como orientador), e de tê-lo em meu comitê de tese. Em determinado momento tive que abandonar o tema inicialmente planejado para a tese, e a escolha de outro tema mostrava-se difícil. Sabedor disso, certo dia Comstock generosamente me emprestou para consulta sua "caixa de idéias", onde guardava dezenas de fichas com idéias e perguntas de pesquisa extremamente interessantes.

Um grande epidemiologista, uma figura humana ímpar.

Eduardo Faerstein

Instituto de Medicina Social, Universidade do Estado do Rio de Janeiro, Rio de Janeiro, RJ

3. In Memoriam: George W. Comstock . Am J Epidemiol 2007; 166:493-4. 